\title{
EFFECTS OF PRODUCTION DIVERSIFICATION IN SPECIALISED DAIRY FARMS - CASE STUDY
}

\begin{abstract}
Specialisation and concentration processes taking place in milk production cause major dependence of farms on the price situation on the market. One of the measures that farmers can take up to mitigate the income variability at the same time keeping the level of professionalisation is differentiation of agricultural production and gaining income from various farm activities. The analysis assessed the effects of horizontal diversification of model dairy farms. The research considered two methods of conducting live cattle production on a farm: keeping a dairy herd and own calves for fattening, and purchase of cattle for fattening. Both strategies assumed reduction of milk production on farms with simultaneous introduction of cattle fattening. The research took account of two scenarios of surrounding conditions. The first one assumes constant conditions of operation of farms in 2013 (excluding direct payments). The second one was based on forecasts of price changes in means of production and manufactured products. Results show that production diversification will bring lower family farm income and management income than in case of keeping high specialisation in milk production. The obtained results, moreover, show that higher profitability in case of production diversification may be true for fattening strategy of cattle from own production.
\end{abstract}

Keywords: strategy, specialisation, family farm income, opportunity costs, live cattle, milk production.

JEL codes: D24, Q12, Q13, Q14, O21. 


\section{Introduction}

Product specialisation in agricultural production allows for a number of both economic and organisational benefits. It is accompanied by a phenomenon of production concentration reflected in a decreasing number of dairy cow holdings coupled with the maintained or increased level of production in the dairy market. This is a consequence of activities taken by holdings mainly in order to increase the stock and cow milk yield. Specialisation and concentration carry, however, a risk of strong dependence of economic results on the prices of the main product of the farm, i.e. milk. When milk quotas were in force, the European milk production market was protected against excessive milk supply, which limited milk price fluctuations, while the direct payment system that was in use also enabled the farmers and their families to obtain income at a satisfactory level and encouraged development of farms. Changes to the EU policy, e.g. as regards the production limits and many important factors of milk production (lower feed prices), led in 2013-2015 to a substantial increase in the EU milk supply. In consequence, the milk prices dropped, which decreased the income generated by the farms. Due to the above mentioned factors, many milk producers are thinking of taking activities to ensure themselves an additional source of income, mainly through diversification of production on the farm.

Given the above, the article aims at determining the economic effects of product diversification by farms specialising in milk production. The accomplishment of this aim will first of all answer the question whether introduction of production of cattle for slaughter will improve economic results of farms and will indicate, at the same time, an economically effective strategy of how such a change could be made.

\section{Typology of strategies of family farms}

The term strategy is differently defined in literature on organisation management. Numerous clarifications of this term even allow for a classification of approaches taken by their authors (Obłój, 2007; Krupski, 2003). In literature on agriculture, a strategy is rather considered from the perspective of survival of family farms and their adaptation to the changing environment. Three basic strategies of family farms are evoked in this context: professionalization, stable reproduction and withdrawal strategies (Fig. 1) (Krammer, Larcher, Vogel and Lautsch, 2012).

Farm professionalization should be understood as a market-oriented strategy which aims at farm development (measured e.g. by the scale of production, income etc.). In this strategy, farms use resources in agricultural production which is the basic source of income in the medium- and long-term. This strategy most often concerns young farmers (business entities) operating large holdings or farmers on small holdings, in the regions where employment possibilities outside farm are limited (Tracy, 1997). Farm professionalism is achieved through specialisation or diversification of activity. 


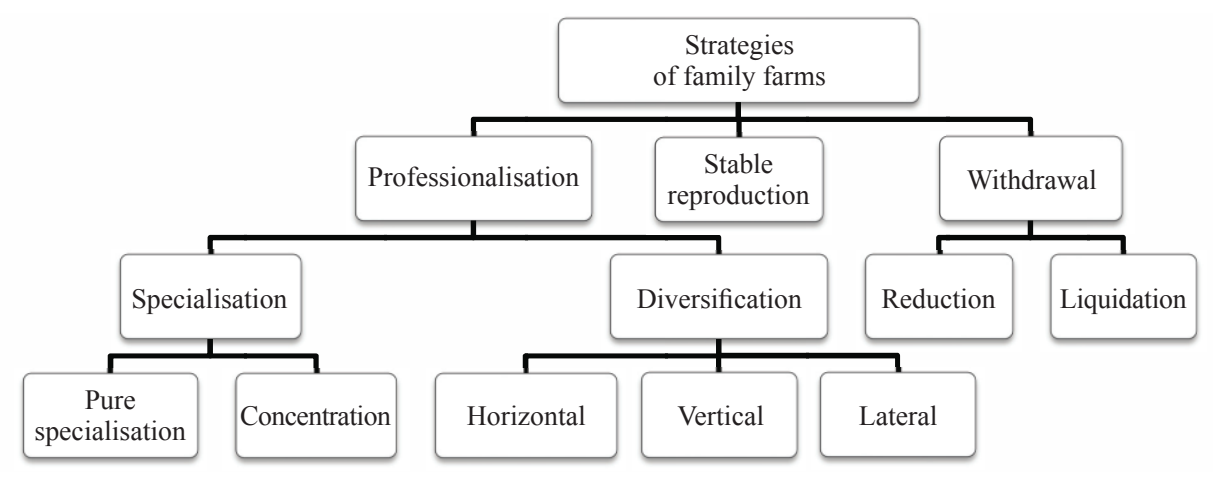

Fig 1. Types of strategies of family farms.

Source: Krammer, Larcher, Vogel and Lautsch (2012), pp. 96-113.

Specialisation is a clear orientation of the farm on the selected branch or activity, which consists in limiting the range of production, e.g. limiting the number of animal species and the number of processing animal groups per herd (Stachak, 1998). This is associated with simplified organisation or production methods (Klepacki, 1997; Kierul and Majewski, 1991), which may lead to lower unit costs of production. Professionalization may be also reflected in the concentration of production, i.e. concentrating the homogeneous production and increasing the scale of production in the same unit that organises the production (Stachak, 1998). The purpose of concentration is to increase economic efficiency (Fereniec, 1999), e.g. by reduced purchase costs, increased use of means of production and labour force (Świtłyk, 1999). In Polish agriculture, the process of specialisation and concentration was introduced for years. The decline in the number of farms occurred along with an increase in the number of those specialising in selected areas of production. According to the data of the Central Statistical Office (GUS), in 2005, there were $45 \%$ of mixed-farming holdings (various crops and livestock), while in 2013, the share of such holdings declined to $31 \%$ (Central Statistical Office (GUS), 2013, 2005). These processes also led to improved land and asset productivity (Ziętara, 2014).

Professionalization can be also achieved through diversification. One of its variants is horizontal diversification which consists in the extension of activity to new branches of production, if they are synergy or complementary to the existing core activity. Diversification activities can be also of vertical character and then they involve the extension of farm's activity through backward or forward integration of its agricultural activity, e.g. by further processing of own products by the farm (Krammer, Larcher, Vogel and Lautsch, 2012). Multidirectional activity is highly beneficial, e.g. it is conducive to reducing the total risk of the holding activity (Jerzak, 2008), achieving the synergistic effect, which makes it possible to rationalise the portfolio of activities (Romanowska, 2004). 
Later diversification of production involves, on the other hand, commencement of activities not related to the existing agricultural activity, but related to agriculture (e.g. ruraltourism, handicraft, services provided with the use of agricultural equipment, etc.). According to the data of the Central Statistical Office (GUS), in 2013 , approximately $37 \%$ of farms (2.6\% of the total number of holdings) conducted such activity, in relation to 2010 , this number decreased, however, by 24\% (GUS, 2013; 2010).

The second main strategy of family farms is stable reproduction relating to entities which do not show significant changes in their activity. This specific state of suspension of a farm may be a prelude to professionalization or withdrawal from the market. This strategy is often applied on farms with unsolved inheritance problems (Methorst, Roep, Verhees and Verstegen, 2016; Mishra, El-Osta and Johnson, 2004).

Withdrawal is the third type of strategies adopted by farms that involves abandoning of agricultural activity. This is most often associated with low income achieved from the farm or inheritance problems. This strategy may consist in the gradual reduction in the use of resources, mainly human resources, for agricultural activity and the focus of farmers on non-agricultural activity. Immediate cessation of agricultural activity, i.e. liquidation of the farm, occurs in connection with retirement of its owner, his poor health or family problems in the absence of a successor.

\section{Research material and method}

The research is based on models of farms. In economic sciences, models are widely applied and make it possible to study quantitative relations between different economic phenomena and to observe the development of these phenomena under assumed conditions (Stachak, 2013).

In the conducted research, a model farm is a set of information describing the holding by means of the technical and economic parameters of farms participating in Polish FADN in 2014 (Goraj, Bocian, Osuch and Smolik, 2016). The research was conducted on the basis of data and measures of farms highly specialised in milk production selected because of their economic value. Given the specific nature of research, analyses have only focussed on medium-large $(50 \leq E U R<100)$ and large $(100 \leq E U R<500)$ farms. These farms achieved income on account of management and risk in 2014; therefore, it was assumed that they are characterised by minimum potential to implement strategic changes. A number of additional assumptions and calculations relating to the organisation of production were made in order to design models of farms. Standards and norms of agricultural production published by the Warsaw University of Life Sciences (SGGW) in Warsaw and the Agricultural Advisory Centre Branch in Poznań were used for this purpose. The farm models were verified in terms of production and economic results in 2014. Basic parameters assumed in the model farms are presented in Table 1. 
Table 1

Basic features of model farms in 2014

\begin{tabular}{|c|c|c|c|}
\hline \multirow{2}{*}{ Parameters } & \multirow{2}{*}{ Unit of measure } & \multicolumn{2}{|c|}{ Model farms } \\
\hline & & M35 & M74 \\
\hline $\begin{array}{l}\text { Dairy cow stock } \\
\text { of a model farm }\end{array}$ & number of pieces & 35 & 74 \\
\hline $\begin{array}{l}\text { Share of milk production } \\
\text { in total production }\end{array}$ & $\%$ & 70 & 75 \\
\hline Cows' milk production & $\mathrm{kg}^{*}$ animal $^{-1}$ & 6,447 & 7,260 \\
\hline Stocking density & $\mathrm{LU}^{*} 100$ ha of $\mathrm{UAA}^{-1}$ & 131 & 143 \\
\hline Farm capital & PLN thousand $*$ ha $^{-1}$ & 27.8 & 28.9 \\
\hline Utilised agricultural area (UAA) & ha & 42.8 & 84.5 \\
\hline $\begin{array}{l}\text { Share of permanent pastures PP } \\
\text { in the area of UAA }\end{array}$ & $\%$ & 36 & 29 \\
\hline Share of leased areas in land resources & $\%$ & 33 & 37 \\
\hline Total labour inputs, including: & hours & 4,579 & 6,296 \\
\hline Share of family labour force & $\%$ & 95 & 77 \\
\hline
\end{tabular}

Source: own work based on: Goraj, Bocian, Osuch and Smolik (2016).

In the model farms, highly specialised in milk production, an assumption was made to rear heifers for herd replacement purposes only, the other animals are sold. Feeding was based on animal feed produced in the holding and purchased.

Two strategies were adopted in the conducted research to diversify activity in the holdings, associated with horizontal diversification of production, i.e. with extension of the activity portfolio, but within the same group of animals, namely cattle. These strategies assume restriction of milk production through a $30 \%$ decrease in the cow herd and commencement of beef cattle production (Table 2). In both strategies, there are the same limitations as regards the possibilities of manufacturing animal feed for own needs and livestock buildings, which means that no changes in land, buildings or equipment were assumed. In the first strategy (S1) an assumption was made to maintain the dairy and fattening herd. Dairy cows are cross-bred with Limousine breed. After calving, male calves are intended for fattening, while female calves are sold. In this strategy, some of the cows are still inseminated with dairy semen, which serves herd replacement purposes. This also means that dairy male calves are sold. The second of the adopted strategies (S2) is based on the purchase of animals for fattening with the weight of approx. 250 kilos (mixed breed), while milk production organisation remains unchanged (with a smaller herd of cows). 
Table 2

Assumptions adopted in the strategies of operation of model farms

\begin{tabular}{lrrrrrr}
\hline \multirow{2}{*}{ Main assumptions of the adopted strategies } & \multicolumn{3}{c}{ M35 } & \multicolumn{3}{c}{ M74 } \\
\cline { 2 - 7 } & B & S1 & S2 & B & S1 & S2 \\
\hline Year when implementation activity commences & 2014 & 2014 & 2016 & 2014 & 2014 & 2016 \\
Year when full production effects are achieved & 2014 & 2016 & 2016 & 2014 & 2016 & 2016 \\
Number of cows in 2016 & 35 & 25 & 25 & 74 & 52 & 52 \\
Milk sales in 2016 (t* year $^{-1}$ ) & 238 & 170 & 170 & 566 & 397 & 397 \\
$\begin{array}{l}\text { Number of animals for fattening sold in 2016 } \\
\text { (number of pieces) }\end{array}$ & - & 7 & 10 & - & 15 & 22 \\
Labour inputs in 2016 (hour*year ${ }^{-1}$ ) & 4,346 & 3286 & 3186 & 6,296 & 5425 & 4820
\end{tabular}

B - a strategy of making no changes to the holding (highly specialised in milk production); S1 - a strategy assuming fattening of own animals; S2 - a strategy assuming fattening of purchased animals

Source: own work.

Two scenarios of conditions of the environment were adopted for research purposes. In order to emphasise the impact of the implemented strategies, a decision was made to apply the scenario in which conditions of the environment do not change (status as of 2013). The second scenario takes into account changes to the conditions of the environment. This scenario adopts, in 2014-2016, changes to the prices of products and means of production on the basis of chain-linked indices, which makes it possible to maintain the specific character of the conditions in the first year of the analysis for each of the farms. The chain-linked indices were calculated on the basis of the data and information published by the Central Statistical Office (GUS) and FADN (Abramczuk, Augustyńska-Grzymek, Czułowska, Jabłoński, Skarżyńska and Żekało, 2015). The chain-linked index is also used in projections regarding the prices of products and means of production. Price forecasts for 2017-2020 are based on information of the World Bank (2016) and the European Commission (2015). Due to lack of available price forecasts, e.g. for some means of production, their level was determined on the basis of average change rate from 2009-2016. In addition, it was assumed that the purchase price of milk will decrease in the adopted strategies owing to a decline in the sales volume. On the basis of analysis of FADN data concerning milk purchase prices in highly specialised dairy farms it was assumed that this price may be reduced by 5\% (Goraj, Bocian, Osuch, and Smolik, 2015; Goraj, Bocian, Osuch, and Smolik, 2016, Bocian, Osuch and Smolik, 2017).

The research uses the TIPI-CAL model (Technology Impact and Policy Impact Calculation). It is a multi-year recursive model, allowing for deterministic 
or stochastic simulation of changes in farms. The model is described in more detail in the publications of its creators and the works of Świtłyk (Hemme, 2000; Deblitz and Świtłyk, 1999).

Outcome categories of farms were calculated in accordance with the FADN methodology. The research uses full cost accounting which allows for determining income on account of management and risk. The economic calculation includes the costs of own factors of production: land, labour, capital (alternative costs). The use of own land was valued in accordance with the previous domestic and foreign studies, i.e. on the basis of average rent (Skarżyńska, 2011; Goraj and Mańko, 2011; European Dairy Farmers, 2012; Hemme (ed.), 2014). The contractual cost of capital for 2017-2020 was estimated on the basis of annual average interest rate on deposits with over two years maturity in commercial banks in the years 2009-2016. Alternative costs of own labour were determined as a product of own labour inputs expressed in full-time employees and average net salary/wage in a given year. The projected salary and wage changes for 2017-2020 were calculated by means of the average rate of change in average gross salaries and wages in the national economy in 2009-2016.

The effects of production diversification were assessed from the view of the achieved economic results, i.e. total production, gross added value, income from a family farm and income on account of management and risk.

\section{Results}

This first scenario assumes the implementation of individual strategies while maintaining the prices of products and means of production at the 2013 level. Direct payments and milk production volume were subject to change. The results of simulations for the first of the analysed farms (M35) are presented in Table 3. Output categories expressed in zloty per farm show that the most favourable situation occurs in case of the lack of production diversification. This is confirmed by the level of income from a family farm and income on account of management and risk. The results for 2018 show that implementation of the strategy consisting in own calves fattening will cause a decrease in income from a family farm by more than PLN 50 thousand, as compared to income achieved when the holding continues to breed dairy cattle only. A similar trend will occur in strategy S2 (purchase of animals for fattening), in which income from a family farm will be lower by nearly PLN 70 thousand, as compared to the situation when the holding is not involved in beef cattle production. As regards income on account of management and risk, the difference is within the range of PLN 40-50 thousand, depending on the implemented strategy. 
Table 3

Selected result categories of the M35 farm simulation in the scenario of unchanged conditions of the environment

\begin{tabular}{|c|c|c|c|c|c|c|c|c|c|}
\hline \multirow{2}{*}{$\begin{array}{l}\text { Farm result } \\
\text { categories }\end{array}$} & \multicolumn{3}{|c|}{ M74 Model Farm } & \multicolumn{3}{|c|}{ Strategy S1 } & \multicolumn{3}{|c|}{ Strategy S2 } \\
\hline & 2014 & 2018 & $\begin{array}{l}2018 / \\
2014\end{array}$ & 2014 & 2018 & $\begin{array}{l}2018 / \\
2014\end{array}$ & 2014 & 2018 & $\begin{array}{l}2018 / \\
2014\end{array}$ \\
\hline \multicolumn{10}{|c|}{ in PLN thousand per farm } \\
\hline Total production & 398.5 & 469.9 & $117.9 \%$ & 398.5 & 377.3 & $94.7 \%$ & 398.5 & 385.5 & $96.7 \%$ \\
\hline Gross value added & 219.5 & 284.5 & $129.6 \%$ & 219.5 & 227.5 & $103.6 \%$ & 219.5 & 212.8 & $96.9 \%$ \\
\hline $\begin{array}{l}\text { Income from } \\
\text { a family farm }\end{array}$ & 160.1 & 224.6 & $140.3 \%$ & 160.1 & 169.9 & $106.1 \%$ & 160.1 & 155.2 & $96.9 \%$ \\
\hline $\begin{array}{l}\text { Income on account of } \\
\text { management and risk }\end{array}$ & 70.2 & 125.6 & $178.9 \%$ & 70.2 & 86.3 & $122.9 \%$ & 70.2 & 75.7 & $107.8 \%$ \\
\hline \multicolumn{10}{|c|}{ in PLN per hour of (own and paid) work } \\
\hline Total production & 87.0 & 102.6 & $117.9 \%$ & 87.0 & 106.0 & $121.8 \%$ & 87.0 & 117.4 & $134.9 \%$ \\
\hline Gross value added & 47.9 & 62.1 & $129.6 \%$ & 47.9 & 63.9 & $133.4 \%$ & 47.9 & 64.8 & $135.3 \%$ \\
\hline $\begin{array}{l}\text { Income from } \\
\text { a family farm }\end{array}$ & 35.0 & 49.0 & $140.0 \%$ & 35.0 & 47.7 & $136.3 \%$ & 35.0 & 47.2 & $134.9 \%$ \\
\hline $\begin{array}{l}\text { Income on account of } \\
\text { management and risk }\end{array}$ & 15.3 & 27.4 & $179.1 \%$ & 15.3 & 24.2 & $158.2 \%$ & 15.3 & 23.0 & $150.3 \%$ \\
\hline
\end{tabular}

Source: own work.

The above-mentioned differences in profitability may give an incomplete picture of changes in the results that have occurred because of the implementation of the adopted strategies. That is why, it was necessary to select a reference unit that would make it possible to compare results between the strategies. It was assumed that own and paid labour inputs will perform the function of such unit. Analysis of income from a family farm shows that extension of production to breeding cattle for slaughter will ensure the M35 holding a similar level of income (2018) as if it simply continued to produce milk. Calculation of income on account of management and risk for 2018 shows that in the two adopted strategies, its level will be nearly identical and will amount to approx. PLN 47 per hour of labour input. This value will be not much lower than income achieved when the farm continues to operate as highly specialised in milk production and will only amount to PLN 1.3-1.8 per hour of work.

The 2019-2020 period was not covered by the conducted analysis because the purpose of the scenario of unchanged conditions of the environment is to show the impact of organisational changes on economic situation of farms excluding changes in the prices of products and means of production. The indicated changes were completed in 2017 . The same situation applies to the results achieved for M74 farm that are included in Table 5. 
Table 4

Selected result categories of the M35 farm simulation in the scenario of changed conditions of the operation of the holding

\begin{tabular}{|c|c|c|c|c|c|c|c|c|c|}
\hline \multirow{2}{*}{$\begin{array}{l}\text { Farm result } \\
\text { categories }\end{array}$} & \multicolumn{3}{|c|}{ M35 Model Farm } & \multicolumn{3}{|c|}{ Strategy S1 } & \multicolumn{3}{|c|}{ Strategy S2 } \\
\hline & 2014 & 2018 & 2020 & 2014 & 2018 & 2020 & 2014 & 2018 & 2020 \\
\hline \multicolumn{10}{|c|}{ in PLN thousand per farm } \\
\hline Total production & 398.5 & 428.9 & 456.0 & 398.5 & 348.9 & 345.9 & 398.5 & 356.3 & 343.8 \\
\hline Gross value added & 219.5 & 229.0 & 250.7 & 219.5 & 185.8 & 177.7 & 219.5 & 172.1 & 154.7 \\
\hline $\begin{array}{l}\text { Income from } \\
\text { a family farm }\end{array}$ & 160.1 & 162.7 & 178.3 & 160.1 & 122.2 & 108.2 & 160.1 & 108.5 & 85.3 \\
\hline $\begin{array}{l}\text { Income on account of } \\
\text { management and risk }\end{array}$ & 70.2 & 46.4 & 42.8 & 70.2 & 22.8 & -7.4 & 70.2 & 14.1 & -24.3 \\
\hline \multicolumn{10}{|c|}{ in PLN per hour of (own and paid) work } \\
\hline Total production & 87.0 & 93.7 & 99.6 & 87.0 & 98.0 & 97.2 & 87.0 & 108.5 & 104.7 \\
\hline Gross value added & 47.9 & 50.0 & 54.8 & 47.9 & 52.2 & 49.9 & 47.9 & 52.4 & 47.1 \\
\hline $\begin{array}{l}\text { Income from } \\
\text { a family farm }\end{array}$ & 35.0 & 35.5 & 38.9 & 35.0 & 34.3 & 30.4 & 35.0 & 33.0 & 26.0 \\
\hline $\begin{array}{l}\text { Income on account of } \\
\text { management and risk }\end{array}$ & 15.3 & 10.1 & 9.3 & 15.3 & 6.4 & -2.1 & 15.3 & 4.3 & -7.4 \\
\hline
\end{tabular}

Source: own work.

The second of the adopted scenarios takes into account the prices of means of production and agricultural products. Included in Table 4 output categories expressed in PLN per farm indicate that the highest income (total production) will be ensured if the farm continues to produce milk. It is expected that in 2020 income from a family farm will increase by approx. $10 \%$ in relation to 2014 . This increase will be determined by the increase in production resulting from lack of the milk quota system and biological progress in farm. Implementation in M35 farm of the strategies of breeding cattle for slaughter with the use of assumptions of the scenario of changes in the prices of means of production and agricultural products gave a negative picture of changes in profitability. In the two analysed strategies, there will be a decrease in income from a family farm between 2014 and 2020 . In strategy S1, it will amount to approx. 32\%, and in strategy S2, it will exceed $46 \%$. When the obtained results are divided by labour input the expected decrease in income will be smaller. Production of beef cattle on the basis of own animals will result in approx. a 13\% decrease in income from a family farm. In the strategy which involves fattening of purchased animals, in 2020, the income will be by $26 \%$ lower than in 2014. Comparative analysis of the adopted strategies shows that the best solution for M35 farm would be to maintain the high-level specialisation in milk production. This will enable, in 2020, to achieve an income by more than PLN 70 thousand higher than in the strategies involving cattle fattening. 
Selected result categories of the $M 74$ farm simulation in the scenario of unchanged conditions of the environment

\begin{tabular}{lccccccccc}
\hline \multirow{2}{*}{$\begin{array}{l}\text { Farm result } \\
\text { categories }\end{array}$} & \multicolumn{3}{c}{ M74 Model Farm } & \multicolumn{3}{c}{ Strategy S1 } & \multicolumn{3}{c}{ Strategy S2 } \\
\cline { 2 - 10 } & 2014 & 2018 & $\begin{array}{r}2018 / \\
2014\end{array}$ & 2014 & 2018 & $2018 /$ & 2014 & 2018 & $2018 /$ \\
& \multicolumn{4}{c}{ in PLN thousand per farm } \\
\hline
\end{tabular}

Source: own work.

While analysing income on account of management and risk, it can be noticed that regardless of whether the analysed farm maintains the existing production or makes attempts at diversification, the income will decrease in 2014-2020. An important issue is the level of the decrease. The smallest decrease, by approx. $40 \%$, is associated with maintaining the milk production direction. When the strategy of cattle fattening is introduced, regardless of the origin of the cattle, in 2020, the income on account of management and risk will reach negative values. Similar trends will occur for changes in the income on account of management and risk achieved per hour of work.

Table 5 presents results of a simulation for the second of the analysed farms (M74) in the scenario of unchanged conditions of the environment. The results of research show that if an farm gets involved in beef cattle production, income from the family farm will decrease. In 2018, in the strategy of own calf fattening, it will reach nearly PLN 371 thousand and will be by $27 \%$ lower than income achieved in case of the lack of production diversification. In strategy S2 (purchase of cattle for fattening), on the other hand, it will amount to PLN 336 thousand. Results expressed in PLN per hour of labour input show that in all the analysed strategies (2018), income from a family farm is within the range of PLN 68-80 per hour. It will be the lowest in the strategy of own calf fattening. Another analysed profitability category was income on account of management 
and risk. In 2018, it will be the lowest if a decision is made to extend production to purchased cattle fattening. In this case, it will amount to PLN 40.6 per hour of work and will be by PLN 2 lower than in the strategy of own cattle fattening.

Selected result categories of the M74 farm simulation

Table 6 in the scenario of changed conditions of the operation of the holding

\begin{tabular}{|c|c|c|c|c|c|c|c|c|c|}
\hline \multirow{2}{*}{$\begin{array}{l}\text { Farm result } \\
\text { categories }\end{array}$} & \multicolumn{3}{|c|}{ M74 Model Farm } & \multicolumn{3}{|c|}{ Strategy S1 } & \multicolumn{3}{|c|}{ Strategy S2 } \\
\hline & 2014 & 2018 & 2020 & 2014 & 2018 & 2020 & 2014 & 2018 & 2020 \\
\hline \multicolumn{10}{|c|}{ in thousand PLN per farm } \\
\hline Total production & 986.4 & 1004.5 & 1070.7 & 986.4 & 800.2 & 798.7 & 986.4 & 809.7 & 790.6 \\
\hline Gross value added & 540.5 & 520.0 & 574.5 & 540.5 & 406.0 & 393.2 & 540.5 & 370.3 & 340.6 \\
\hline $\begin{array}{l}\text { Income from } \\
\text { a family farm }\end{array}$ & 388.9 & 351.1 & 385.4 & 388.9 & 252.7 & 221.4 & 388.9 & 220.6 & 172.7 \\
\hline $\begin{array}{l}\text { Income on account of } \\
\text { management and risk }\end{array}$ & 264.5 & 179.0 & 179.2 & 264.5 & 88.3 & 26.8 & 264.5 & 56.0 & -21.1 \\
\hline \multicolumn{10}{|c|}{ in PLN per hour of (own and paid) work } \\
\hline Total production & 156.7 & 159.5 & 170.0 & 156.7 & 147.5 & 147.2 & 156.7 & 168.0 & 164.0 \\
\hline Gross value added & 85.8 & 82.6 & 91.2 & 85.8 & 74.8 & 72.5 & 85.8 & 76.8 & 70.7 \\
\hline $\begin{array}{l}\text { Income from } \\
\text { a family farm }\end{array}$ & 61.8 & 55.8 & 61.2 & 61.8 & 46.6 & 40.8 & 61.8 & 45.8 & 35.8 \\
\hline $\begin{array}{l}\text { Income on account of } \\
\text { management and risk }\end{array}$ & 42.0 & 28.4 & 28.5 & 42.0 & 16.3 & 4.9 & 42.0 & 11.6 & -4.4 \\
\hline
\end{tabular}

Source: own work.

In the scenario taking into account future development of prices of means of production and agricultural products, the extension of the production to cattle for slaughter will negatively impact profitability of M74 farm (Table 6). Adoption of the assumptions of the strategy involving own cattle breeding will result in lower income achieved by the family farm compared to the lack of diversification of production. In 2020, the difference will amount to approx. PLN 165 thousand. It will be higher when the second of the adopted strategies is implemented. It is estimated that in case of this strategy, the difference in 2020 will be more than PLN 210 thousand. Information included in Table 6, on the amount of income on account of management and risk per hour of work, confirm, the less favourable situation of the farm in connection with a decision to diversify production. The results obtained for 2020 show that implementation of the strategy involving own cattle fattening will ensure income on account of management and risk at the level of approx. PLN 5 per hour of work. This means that the income will be by approx. PLN 24 lower than in case of the lack of diversification of production. In the second of the adopted strategies, income on account of management and risk will be gradually decreasing, and in 2020 it will reach a negative value. 


\section{Conclusions}

Diversification of production may become an indispensable strategy for achieving income levels that would satisfy agricultural producers. The measures taken by the European Union to further liberalise individual agricultural markets are the main determinants of the process leading to diversification of agricultural production. Thus, agricultural producers should consider the possibility of deciding to extent the range of production reducing, at the same time, the burdens resulting from the need to engage additional factors of production. It seems that the least complex activities are associated with diversification of production on milk producing farms, which can be also involved in beef cattle production.

The purpose of the conducted research is to provide data, for instance, on differences between future income of dairy farms depending on the adopted strategy involving expansion to production of cattle for slaughter. Results of the conducted simulations show that the highest income from a family farm and income on account of management and risk will be ensured if the farm maintains the highlevel specialisation in milk production. Analysis of results obtained from the strategies adopted for research purposes involving beef cattle production shows that the farm will be ensured higher profitability if it adopts the strategy involving milk production along with own cattle fattening. In case of this strategy income from a family farm in 2020 will be higher by approx. 26-28\% than income achieved by the analysed farm in the strategy involving purchase of animals for further fattening (strategy S2). Calculation of income on account of management and risk taking account of the costs of alternative use of own factors of production shows that in 2020, in case of strategy S2, such income for both model farms will assume a negative value.

It should be noted that the research conducted is a starting point for further analyses as regards assessment of the effects of production diversification on dairy farms. A subsequent step will be to assess the income risk incurred due to changes in the milk and beef cattle purchase prices. 


\section{References}

Abramczuk, Ł., Augustyńska-Grzymek, I., Czułowska, M., Jabłoński, K., Skarżyńska, A., Żekało, M. (2015). Wskaźniki zmian kosztów bezpośrednich i cen podstawowych produktów rolnych $w$ latach 2014-2015. Warsaw: IERiGŻ-PIB.

Bocian, M., Osuch, D., Smolik, A. (2017). Parametry techniczno-ekonomiczne według grup gospodarstw rolnych uczestniczacych $w$ polskim FADN $w 2015$ r. Warsaw: IERiGŻ-PIB.

Deblitz, C., Świtłyk, M. (1999). Zastosowanie modelu TIPI-CAL do budowy międzynarodowej sieci gospodarstw porównawczych. W: Strategia rozwoju obszarów wiejskich $w$ warunkach reformy ustrojowej państwa i procesów integracji europejskiej. Akademia Rolnicza w Szczecinie, Akademia Rolniczo-Techniczna w Olsztynie, t. 1, pp. 369-383.

European Commission (2015). EU Agricultural Outlook. Prospects for EU agricultural markets and income 2015-2025. Brussels: European Union.

European Dairy Farmers (2012). EDF Raport 2012. Braunschweig: Federal Research Institute for Rural Areas, Forestry and Fisheries, Institute of Farm Economics.

Fereniec, J. (1999). Ekonomika i organizacja rolnictwa. Warsaw: Wydawnictwo Key Text.

Goraj, L., Bocian, M., Osuch, D., Smolik, A. (2015). Parametry techniczno-ekonomiczne według grup gospodarstw rolnych uczestniczacych w Polskim FADN w 2013 r. Warsaw: IERiGŻ-PIB.

Goraj, L., Bocian, M., Osuch, D., Smolik, A. (2016). Parametry techniczno-ekonomiczne według grup gospodarstw rolnych uczestniczacych w Polskim FADN w 2014 r. Warsaw: IERiGZ̈-PIB.

Goraj, L., Mańko, S. (2011). Model szacowania pełnych kosztów działalności gospodarstw rolnych. Zagadnienia Ekonomiki Rolnej, no. 3(328), pp. 28-58.

GUS (2006). Charakterystyka gospodarstw rolnych w 2005 r. Warsaw.

GUS (2011). Charakterystyka gospodarstw rolnych $w 2010 \mathrm{r}$. Warsaw.

GUS (2014). Charakterystyka gospodarstw rolnych $w 2013$ r. Warsaw.

Hemme, T. (2000). IFCN - A concept for international analysis of the policy and technology impacts in agriculture. Ein Konzept zur international vergleichenden Analyse von Politik- und Technikfolgen in der Landwirtschaft. Landbauforschung Völkenrode, Sonderheft 215, Braunschweig (Dissertation).

Hemme, T. (ed.). (2014). IFCN Dairy Report 2013. Kiel: IFCN.

Jerzak, M. (2008). Indywidualne instrumenty zarządzania ryzykiem produkcyjnym, dochodowym i cenowym w rolnictwie. W: M. Hamulczuk, S. Stańko (ed.), Zarzadzanie ryzykiem cenowym a możliwości stabilizowania dochodów producentów rolnych, IERiGŻ-PIB, pp. 59-72.

Kierul, Z., Majewski, E. (1991). Postep techniczny w gospodarstwie rolniczym. Warsaw: Państwowe Wydawnictwo Rolnicze i Leśne.

Klepacki, B. (1997). Wybrane pojęcia z zakresu organizacji gospodarsw, produkcji i pracy w rolnictwie. Warsaw: Wydawnictwo SGGW.

Krammer, M., Larcher, M., Vogel, S., Lautsch, E. (2012). The pattern of Austrian dairy farm houshold strategies. German Journal of Agriculture Economics, t. 61, no. 2, pp. 96-113.

Krupski, R. (ed.). (2003). Strategie i zarządzanie strategiczne. W: Zarzadzanie strategiczne. Koncepcje - metody. Wrocław: Wydawnictwo Akademii Ekonomicznej im. Oskara Langego we Wrocławiu. 
Methorst, R.G., Roep, D., Verhees, F.J.,Verstegen, J.A. (2016). Drivers for differences in dairy farmers perceptions of farm development strategies in an area with nature and landscape as protected public goods. Local Economy, vol. 31, no. 5, pp. 554-571.

Mishra, A.K., El-Osta, H.S., Johnson, J.D. (2004). Succession in family farm business: empirical evidence from the U.S.farm sector. Presentation at the AAEA Meeting in Denver. Pobrane z: http://purl.umn.edu/20114.

Obłój, K. (2007). Strategie organizacji. Warsaw: Polskie Wydawnictwo Ekonomiczne.

Romanowska, M. (2004). Planowanie strategiczne $w$ przedsiębiorstwie. Warsaw: Polskie Wydawnictwo Ekonomiczne.

Skarżyńska, A. (2011). Koszty ekonomiczne produkcji mleka - metodyczne ujęcie rachunku oraz wyniki badań w 2009 roku. Zagadnienia Ekonomiki Rolnej, no. 3(328), pp. 143-161.

Stachak, S. (1998). Ekonomika agrofirmy. Warsaw: Wydawnictwo Naukowe PWN.

Stachak, S. (2013). Podstawy metodologii nauk ekonomicznych. Gdańsk: Difin.

Świtłyk, M. (1999). Zarys nauki o zarządzaniu przedsiębiorstwem rolniczym. Szczecin: Wydawnictwo Akademii Rolniczej w Szczecinie.

Tracy, M. (1997). Polityka rolno-żywnościowa $w$ gospodarce rynkowej. Wprowadzenie do teorii i praktyki. Warsaw: Wydawnictwo Olympus Centrum Edukacji i Rozwoju Biznesu.

World Bank (2016). Commodity Markets Outlook. Washington: World Bank Group.

Ziętara, W. (2014). Koncentracja i specjalizacja gospodarstw rolniczych w procesie integracji z Unią Europejską. Zeszyty Naukowe Szkoły Głównej Gospodarstwa Wiejskiego $w$ Warszawie. Problemy Rolnictwa Światowego, vol. 29, no. 1, pp. 157-169. 
ARTUR WILCZYŃSKI

EWA KOEOSZYCZ

Zachodniopomorski Uniwersytet Technologiczny

Szczecin

\title{
SKUTKI DYWERSYFIKACJI PRODUKCJI W SPECJALISTYCZNYCH GOSPODARSTWACH MLECZNYCH - STUDIUM PRZYPADKU
}

\begin{abstract}
Abstrakt
Procesy specjalizacji i koncentracji zachodzace w produkcji mleka powoduja duże uzależnienie gospodarstw od sytuacji cenowej na rynku. Jednym $z$ działań, jakie moga podjać rolnicy $w$ celu ograniczenia zmienności dochodów, przy jednoczesnym utrzymaniu stopnia profesjonalizacji, jest zróżnicowanie produkcji rolniczej $i$ osiaganie dochodów z różnych działalności w gospodarstwie. W badaniach oceniono skutki dywersyfikacji poziomej modelowych gospodarstw mlecznych. Pod uwage wzięto dwa sposoby prowadzenia produkcji żywca wołowego w gospodarstwie: utrzymywanie stada mlecznego wraz z opasaniem własnych cielat oraz zakup zwierzat przeznaczonych do opasania. Obie strategie zakładały ograniczenie produkcji mleka $w$ gospodarstwach przy jednoczesnym wprowadzeniu opasu bydta. W badaniach uwzględniono dwa scenariusze warunków otoczenia. Pierwszy zakładał stałe warunki działania gospodarstw z 2013 r. (poza płatnościami bezpośrednimi). Drugi scenariusz opierał się na prognozach zmian cen środków produkcji oraz wytwarzanych produktów. Wyniki wskazuja, że różnicowanie produkcji przyniesie niższy dochód z rodzinnego gospodarstwa rolnego oraz dochód z tytułu zarzadzania niż w przypadku utrzymania wysokiej specjalizacji w produkcji mleka. Uzyskane wyniki oznaczaja ponadto, że wyższa dochodowość $w$ sytuacji różnicowania produkcji może wystapić $w$ strategii opasania bydła pochodzacego z własnej produkcji.
\end{abstract}

Słowa kluczowe: strategia, specjalizacja, dochód z rodzinnego gospodarstwa rolnego, koszty alternatywne, żywiec wołowy, produkcja mleka.

Accepted for print: 15.12.2017.

Unless stated otherwise all the materials on the website are available under the Creative Commons Attribution 3.0 Poland license. Some rights reserved to the Institute of Agricultural and Food Economics - National Research Institute.

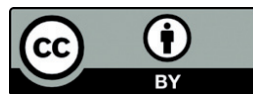

